\title{
Astyanax henseli, a new name for Tetragonopterus aeneus Hensel, 1870 from southern Brazil (Teleostei: Characiformes)
}

\author{
Filipe A. G. de Melo and Paulo A. Buckup
}

Tetragonopoterus aeneus Hensel (1870) is removed from synonymy with Astyanax fasciatus (Cuvier, 1819), revalidated and redescribed as $A$. henseli to avoid homonymy. Astyanax henseli differs from A. fasciatus stricto sensu and other Astyanax species by the presence of two to four maxillary teeth, two vertically-elongated humeral spots, dentary tooth cusps positioned close to one another, and the slender form of the dentary teeth.

Tetragonopterus aeneus Hensel (1870) é retirada da sinonimia de Astyanax fasciatus (Cuvier, 1819), revalidada e redescrita como $A$. henseli para evitar homonímia. Astyanax henseli diferencia-se de A. fasciatus stricto sensu e das demais espécies de Astyanax pela presença de dois a quatro dentes no maxilar, duas manchas humerais verticalmente alongadas, cúspides dos dentes do dentário situadas próximas entre si, e dentes do dentário relativamente estreitos.

Key words: taxonomy, Astyanax fasciatus, species complex, rio Jacuí, fish, freshwater.

\section{Introduction}

The characid genus Astyanax Baird \& Girard, 1854, includes 92 valid and more than one hundred nominal species ranging from Texas to northeastern Argentina (Azpelicueta et al., 2002; Azpelicueta et al., 2003; Casciotta et al., 2003; Lima et al., 2003:106; Lima \& Jahnsen, 2004; Bertaco \& Lucinda, 2005; Haluch \& Abilhoa, 2005). Eigenmann (1921, 1927) was the only author who revised the genus Astyanax. That revision is now outdated and the monophyly of Astyanax, as currently defined, is not corroborated by any synapomorphy (Weitzman \& Fink, 1983; Weitzman \& Malabarba, 1998; Zanata, 1997).

Hensel (1870) described Tetragonopterus aeneus as a new species, based on a single specimen from Porto Alegre, Southern Brazil. That name, however, is a junior homonym of Tetragonopterus aeneus Günther (1860), a species previously described based on specimens from Oaxaca, Mexico.

Steindachner (1876) listed Tetragonopterus aeneus Hensel (1870) as a synonym of Tetragonopterus rutilus Jenyns (1842), along with T. obscurus Hensel (1870). Later, Eigenmann (1910) transferred most species of Tetragonopterus to the genus Astyanax. Tetragonopterus rutilus, T. aeneus Günther, and T. aeneus Hensel were later listed as junior synonyms of Astyanax fasciatus Cuvier (1819) by Eigenmann (1921:293). Astyanax fasciatus, as defined by Eigenmann (1921), was a wide ranging taxon including five subspecies, encompassing the distri- butions of Tetragonopterus aeneus Günther (listed as a synonym of Astyanax fasciatus aeneus) and Tetragonopterus aeneus Hensel (as a synonym of Astyanax fasciatus fasciatus). The fact that Eigenmann (1921) considered T. aeneus Günther and $T$. aeneus Hensel as conspecific taxa obscured the otherwise obvious homonymy.

Through most of the $20^{\text {th }}$ Century, Tetragonopterus aeneus Hensel continued to be regarded as a junior synonym of $A$. fasciatus (e.g. Fowler, 1948), or has been treated as a species of uncertain status (e.g. Malabarba, 1989, who listed it as "Astyanax aff. fasciatus", along with T. obscurus). Eigenmann (1921) proposed the following diagnostic attributes of Astyanax fasciatus: aligned predorsal scales, third infra orbital not covering the cheek, elongated umeral spot, 25 or more anal-fin rays, a silvery lateral band becoming black on the caudal peduncle and continued as a black streak to the end of middle fin rays, origin of dorsal fin equally distant from snout to caudal fin and one or more maxillary teeth, rarely three. Recently, however, several authors (Garruti \& Britski 2000:84; Lozano-Vilano \& Contreras-Balderas, 1990; SchmitterSoto, 1998; Melo, 2001) questioned the validity of $A$. fasciatus sensu Eigenmann (1921) and suggested that many species may be included in Eigenmann's (1921) broad definition of $A$. fasciatus. Here we refer to these species as the "Astyanax fasciatus species complex". Buckup in Lima et al. (2003:111) recognized the southern Brazilian taxon as a valid species,

Departamento de Vertebrados, Museu Nacional, Universidade Federal do Rio de Janeiro, Quinta da Boa Vista, 20940-040 Rio de Janeiro, RJ, Brazil. 
separate from $A$. fasciatus. Those authors, however, maintained an association between T. obscurus and T. aeneus Hensel, and used $A$. obscurus as the valid name.

As part of an ongoing revision of the Astyanax fasciatus species complex, we examined the holotypes of Tetragonopterus aeneus Hensel and Tetragonopterus rutilus and the syntypes of Tetragonopterus aeneus Günther and Tetragonopterus obscurus, and concluded that they represent four different (valid) species. Here we describe Astyanax henseli as a new name to replace $A$. aeneus (Hensel, 1870), which remains unavailable more than a century after its original publication.

\section{Material and Methods}

Counts and measurements follow Fink \& Weitzman (1974). Additional measurements include (1) the distance between the dorsal-fin origin and the adipose fin, (2) the distance between the anal-fin origin and the tip of the longest ray (3) the distance between the dorsal-fin origin and the tip of longest ray. For counts recorded in the description of the species the observed range is followed in parentheses by the mean and total number (n) of specimens. Morphometric data for the holotype are presented separately in the tables. All measurements other than standard length (SL) are expressed as a percentage of SL except subunits of the head, which are recorded as a percentage of head length (HL). In all tables, SD stands for 'standard deviation', and $\mathrm{n}$ stands for the number of specimens measured. Vertebral counts were taken from radiographs, and cleared and counterstained (c\&s) specimens according to Taylor \& Van Dyke (1985). This number includes the four vertebrae incorporated in the Weberian apparatus and considers the fused $\mathrm{PU}_{1}+\mathrm{U}_{1}$ as a single element. The following acronyms are used for institutions and collections: ANSP, Academy of Natural Sciences, Philadelphia; MCP, Museu de Ciências e Tecnologia da Pontifícia Universidade Católica do Rio Grande do Sul, Porto Alegre; MCZ, Museum of Comparative Zoology, Cambridge, Massachusets; BMNH, Natural History Musem, London; MNHN, Museum National D'historie Naturelle, Paris; MNRJ, Museu Nacional, Universidade Federal do Rio de Janeiro, Rio de Janeiro; MZUSP, Museu de Zoologia da Universidade de São Paulo, São Paulo; UMZC, University Museum of Zoology Cambridge, Cambridge; ZMB, Zoologische Museum Berlin, Berlin.

\section{Astyanax henseli, nomen novum} Figs. 1-4

Tetragonopterus aeneus Hensel, 1870:87-88 (original description). Type locality: Porto Alegre.

Tetragonopterus rutilus Jenyns, 1842 in part - Steindachner, 1876 (T. aeneus Hensel listed as junior synonym).

Astyanax fasciatus (Cuvier, 1819) in part - Eigenmann, 1921

(T. aeneus Hensel listed as junior synonym); Fowler, 1948

(T. aeneus Hensel listed as junior synonym).

Astyanax aff. fasciatus (Cuvier, 1819) in part - Malabarba,
1989 (T. aeneus Hensel listed as junior synonym). Astyanax obscurus (Hensel, 1870) in part - Lima et al., 2003

(T. aeneus Hensel listed as junior synonym).

Diagnosis. Astyanax henseli differs from other Astyanax species except $A$. saguazu Casciotta et al. and A. elachylepis Bertaco \& Lucinda by the presence of a second vertically elongate humeral spot ( $v s$. one elongate humeral spot). Astyanax henseli is distinguished from A. saguazu, A. elachylepis and members of the Astyanax fasciatus species complex by the autapomorphic presence of a space between the dentary teeth, which are relatively slender, with cusps positioned close to one another (Figs. 1-2), and by the presence of a maximum of five cusps in each dentary tooth $(v S$. maximum of seven cusps). Astyanax henseli is also distinguished from A. fasciatus, A. rutilus, and A. elachylepis by the presence of two to five, usually five, tricuspid teeth, on the anterior margin of maxilla ( $v s$. one to two teeth, usually one, on anterior margin of maxilla).

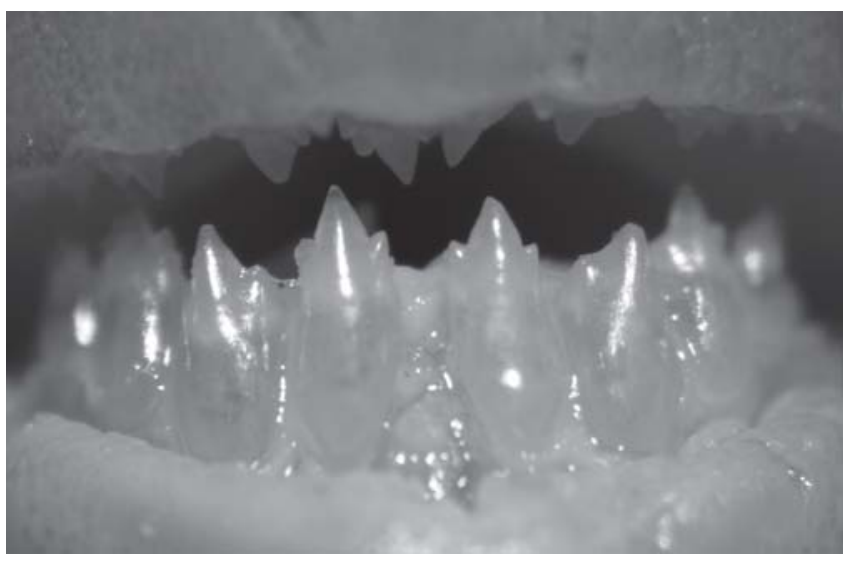

Fig. 1. Frontal view of dentary teeth of Astyanax henseli, MNRJ 22214, $70.2 \mathrm{~mm} \mathrm{SL}$, rio Forqueta, tributary of the rio Taquari, Rio Grande do Sul, Brazil.

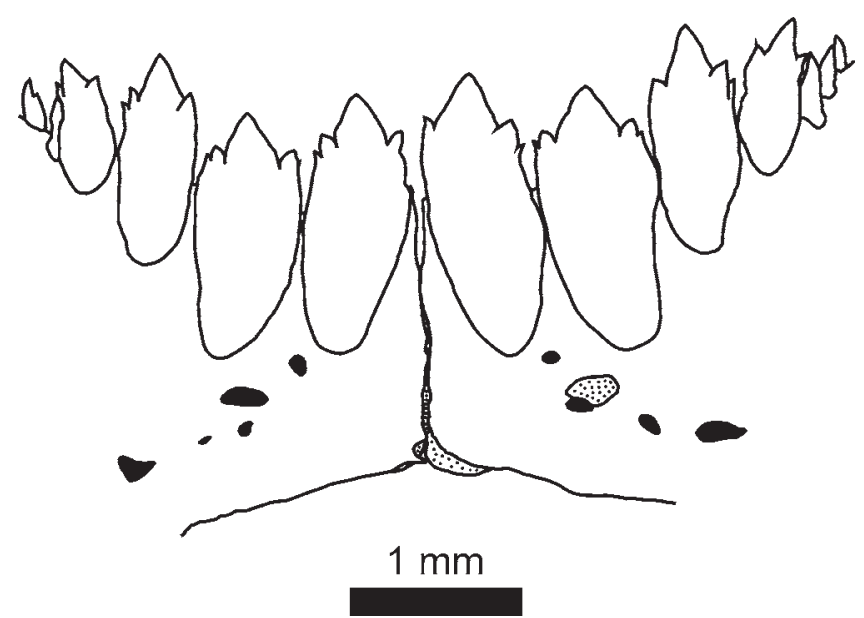

Fig. 2. Frontal view of dentary teeth of Astyanax henseli, MNRJ 14186, arroio do Carvalho, Vila do Carvalho, on road Santo Antônio da Patrulha - Vila Caraá, rio dos Sinos drainage, Rio Grande do Sul, Brazil. 


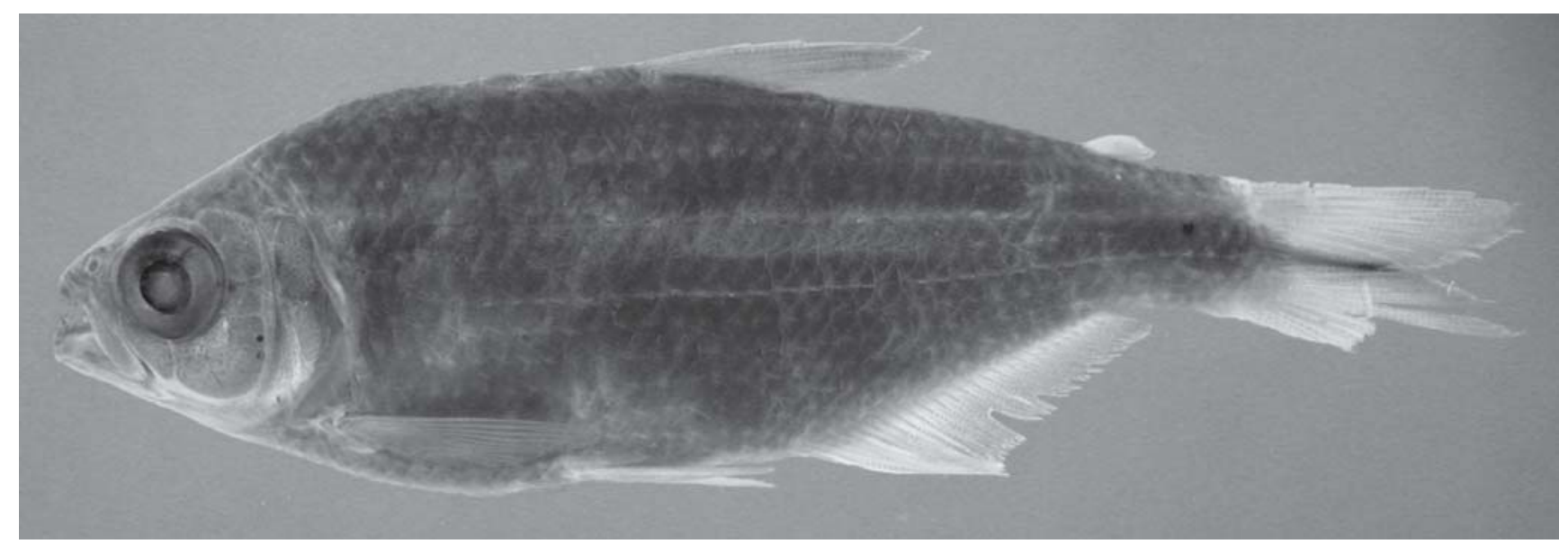

Fig. 3. Astyanax henseli, ZMB 7479, 78.0 mm SL, holotype, male, Porto Alegre, Rio Grande do Sul, Brazil.

Description. Morphometric data are presented in Table 1. Body moderately elongate and compressed (Figs. 3-4); deepest at dorsal-fin origin. Dorsal body profile convex from snout to dorsal-fin origin, straight along dorsal-fin base, slightly convex between insertion of last dorsal-fin ray and adipose fin. Ventral profile of head and abdomen convex; straight along anal-fin base. Dorsal and ventral profiles of caudal peduncle slightly concave.

Snout convex. First infraorbital expanded over small portion of maxilla. Two series of premaxillary teeth; teeth of outer series usually tricuspid, smaller than those of inner series, numbering four to five, usually five; teeth in inner series five with three to seven cusps. Two to five tricuspid teeth on anterior margin of maxilla, usually five teeth (mean=4.7, $n=25$ ). Dentary teeth slender, more so in young specimens; anterior four to five teeth larger than remaining teeth; larger teeth with three to five cusps; fifth tooth usually with three cusps; remaining teeth with one or two cusps. Space between dentary teeth, wider in young specimens.

Dorsal-fin rays ii,8-9 (mean $=9.0, n=25)$; first unbranched ray about half the length of second unbranched ray. Dorsalfin origin located just anterior to middle of body. Adipose-fin origin located dorsal to posterior anal-fin ray insertion. Pectoral-fin rays $\mathrm{i}, 11-13$ (mean $=12.6, \mathrm{n}=25)$; tip of longest ray extending to or posterior to pelvic-fin origin in both males and females. Pelvic-fin rays i,7; pelvic-fin origin anterior to vertical line passing through dorsal-fin origin; longest pelvic ray reaching anal-fin origin in both sexes. Anal-fin rays iiivi,22-27 (mean=24.3, $n=25)$. Anal-fin origin posterior to vertical line through dorsal-fin origin.

Scales cycloid, moderately large. Lateral line complete with $37-41$ scales $($ mean=38.4. $n=22)$. Scale rows between dorsalfin origin and lateral line seven to eight (mean=7.1, $n=25$ ). Scale rows between lateral line and anal-fin origin six to seven $($ mean $=6.4, n=25)$. Predorsal scales $11-16($ mean=13.1, $n=24)$ regularly arranged. Scale sheath on anal-fin base consisting of one row with eight to 17 scales covering bases of unbranched rays and eight to 17 anterior branched rays. Scales around caudal peduncle $15-17($ mean $=15.8, \mathrm{n}=20)$.

Color in alcohol. Body pale brownish yellow. Lateral body stripe broad and dark posteriorly, becoming pale and narrow anterior to dorsal-fin origin. Lateral body stripe silvery in some specimens. Two dark humeral spots, slanted posteriorly and

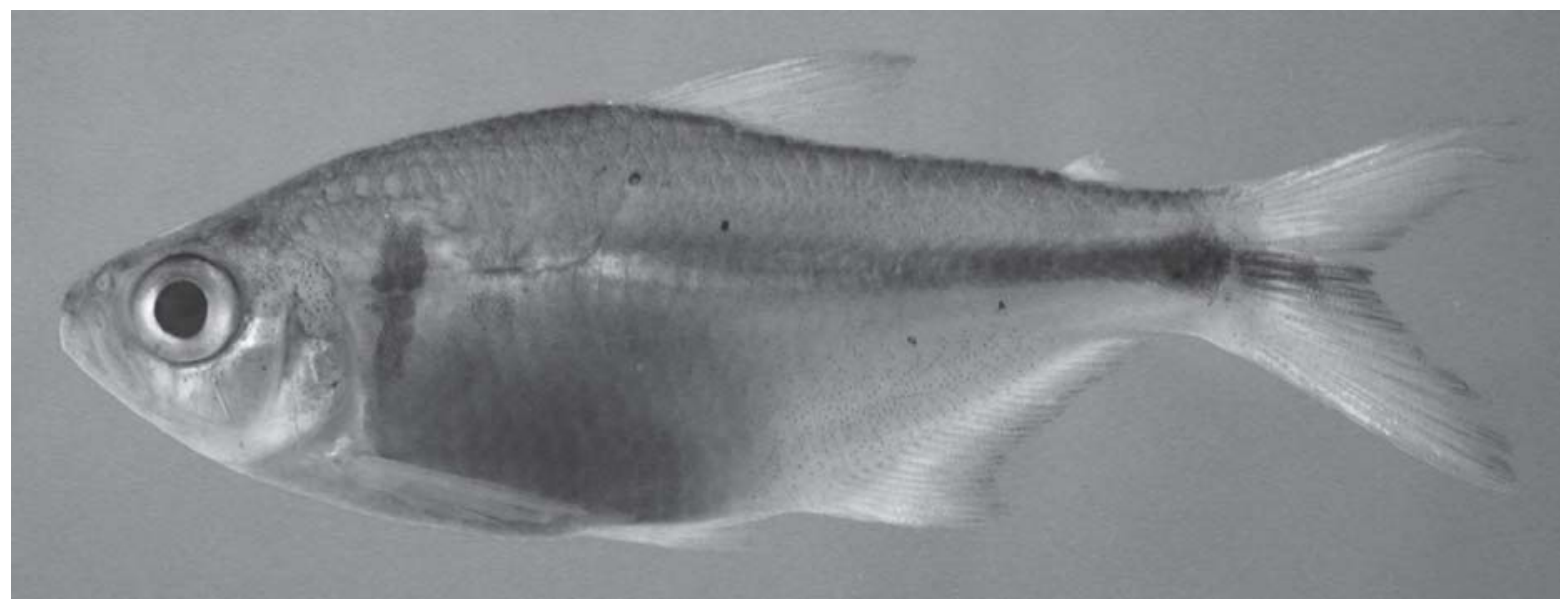

Fig. 4. Astyanax henseli, MNRJ 14186, $64.5 \mathrm{~mm}$ SL, female, arroio do Carvalho, rio dos Sinos drainage, Vila do Carvalho, na estrada Santo Antônio da Patrulha - Vila Caraá, Santo Antônio da Patrulha, Rio Grande do Sul, Brazil. 
Table 1. Morphometric data for Astyanax henseli. Measurements based on the holotype ZMB 7479, and non types specimens MNRJ 14186, MNRJ 22174, MNRJ 22214, and MNRJ 22231. (Hol, holotype; m, males; f, females).

\begin{tabular}{lccccc}
\hline Measurement & Hol & Range & Mean & SD & N \\
\hline Standard length (mm) & 78.0 & $28.9-108.4$ & 63.8 & 18.0 & 24 \\
Head length (mm) & 20.3 & $9.1-26.7$ & 17.4 & 3.9 & 24 \\
& \multicolumn{2}{c}{ Percents of standard length } & & & \\
Body depth (m) & 35.8 & $38.1-40.0$ & 39.2 & - & 3 \\
Body depth (f) & - & $34.5-40.5$ & 37.6 & 1.5 & 21 \\
Head length & 26.1 & $24.6-31.6$ & 27.8 & 1.6 & 24 \\
Caudal peduncle depth & 11.8 & $8.8-14.6$ & 11.2 & 1.2 & 24 \\
Snout to dorsal-fin origin & 51.5 & $51.4-56.7$ & 53.5 & 1.2 & 24 \\
Snout to anal-fin origin & 62.5 & $64.2-67.5$ & 66.1 & 0.9 & 24 \\
Snout to pelvic-fin origin & 46.0 & $47.2-51.4$ & 49.3 & 0.9 & 24 \\
Snout to pectoral fin origin & 25.7 & $25.9-31.4$ & 28.8 & 1.5 & 24 \\
Dorsal-fin origin to caudal-fin origin & 54.2 & $48.3-56.5$ & 52.5 & 1.7 & 24 \\
Anal-fin base & 29.5 & $27.7-32.0$ & 29.7 & 1.3 & 24 \\
Length of longest anal-fin ray (m) & 18.9 & $18.2-20.2$ & 19.5 & - & 3 \\
Length of longest anal-fin ray (f) & - & $17.5-24.2$ & 21.5 & 1.6 & 21 \\
Dorsal-fin origin to adipose-fin origin & 38.4 & $35.0-39.3$ & 37.1 & 1.3 & 24 \\
Dorsal-fin base & 13.1 & $12.1-15.0$ & 13.4 & 0.7 & 24 \\
Length of longest pectoral-fin ray (m) & 22.4 & $22.1-24.5$ & 23.7 & - & 3 \\
Length of longest pectoral-fin ray (f) & - & $21.3-24.9$ & 23.5 & 0.9 & 21 \\
Length of longest pelvic-fin ray (m) & 17.3 & $16.8-18.2$ & 17.7 & - & 3 \\
Length of longest pelvic-fin ray (f) & - & $16.2-19.0$ & 17.7 & 0.7 & 21 \\
Caudal peduncle length & 12.2 & $8.8-14.6$ & 11.2 & 1.2 & 24 \\
Eye to dorsal-fin origin & 39.3 & $37.2-42.4$ & 39.3 & 1.1 & 24 \\
& Percents of head length & & & \\
Snout length & 18.5 & $16.9-24.0$ & 20.2 & 1.6 & 24 \\
Orbital diameter & 45.5 & $42.4-50.7$ & 46.7 & 1.7 & 22 \\
Interorbital width & 29.3 & $27.2-36.0$ & 30.0 & 2.0 & 24 \\
Upper jaw length & 45.9 & $42.9-48.9$ & 46.0 & 1.4 & 24 \\
\hline \multicolumn{7}{c}{} & & & & &
\end{tabular}

slightly wider dorsally; first spot vertically elongate, centered on third and fourth scales of scale row just dorsal to lateral line; second spot, very diffuse, located on first series of scales above lateral line, between seventh to tenth series of scales and extending over two or three horizontal series of scales. Middle caudal-fin rays darkly pigmented with pigmentation extending to tips of rays. Exposed borders of scales delineated by dark chromatophores. Dorsal and anal fins covered with scattered dark chromatophores, except for distinct unpigmented area at tip of dorsal fin and tip of anterior anal-fin lobe. Adipose fin mostly white. Head black to gray dorsally, especially dark near nape. Sides of head and opercles silvery.

Sexual dimorphism. When present, sexual bony hooks distributed over anal-fin and pelvic-fin rays. Pelvic fins with retrorse bony hooks on branched rays and posterior unbranched rays. Anal-fin rays of males with small retrorse bony hooks present from longest unbranched ray to last branched ray; hooks mostly present on posterior branches of rays; one pair of bony hooks per ray segment. Females without fin hooks (gonad examined in specimen MNRJ 14186, $60.8 \mathrm{~mm} \mathrm{SL}$ ).

Distribution. Known from the rio dos Sinos and rio Taquari drainages in Southern Brazil. Rio dos Sinos and rio Taquari are tributaries of the lago Guaíba which is located next to the city of Porto Alegre, and is the northernmost component of the laguna dos Patos system.
Etymology. The specific name henseli is in homage to R. Hensel for his contributions to Ichthyology in Southern Brazil.

Material examined: All specimens from Rio Grande do Sul, Brazil. Holotype: ZMB 7479, (78.0 mm SL, male) Porto Alegre, R. Hensel. Non-types: MNRJ 14186 (15, 1 c\&s, measured, 64.5-28.9 mm SL), MNRJ 14297 (6, 20.5-27.7 mm SL), arroio do Carvalho, Vila do Carvalho, on road from Santo Antônio da Patrulha to Caraá, rio dos Sinos drainage, Santo Antônio da Patrulha, $29^{\circ} 45^{\prime} \mathrm{S} 50^{\circ} 25^{\prime} \mathrm{W}$, 12 Jan 1995. MNRJ 14295 (6, 18.3-26.8 mm SL), rio dos Sinos, at Passo da Forquilha (?), near road crossing road from Caraá to Vila Rodolfo Tetour, Santo Antônio da Patrulha, 29 45'S 50²5'W, 12 Jan 1995. MNRJ 14296 (12, 14.8-34.2 mm SL), rio dos Sinos near bridge on road to Fundo Quente, upstream from rio dos Sinos, Santo Antônio da Patrulha, 2945'S 50²5'W, 12 Jan 1995. MNRJ 22174 (2, measured, 91.4-108.4 mm SL), arroio do Meio, tributary of rio Taquari, Arroio Grande, 28 Nov 1999. MNRJ 22214 (1, measured, $70.2 \mathrm{~mm} \mathrm{SL}$ ) rio Forqueta, tributary of rio Taquari, in the extension area of the Salto Forqueta Hydroelectric dam, 29 $4^{\prime} 37^{\prime \prime} \mathrm{S}$ 52¹2'59"W, 9 May 2001. MNRJ 22231 (6, measured, 73.2-89.3 $\mathrm{mm}$ SL), same locality of MNRJ 22214, 10 May 2001. MCP 11223 (5 of 16, 58.6-85.0 mm SL), rio Cadeia on BR116 highway, be-

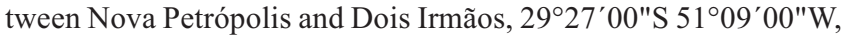
30 Apr 1987. MCP 18396 (5 of 63, 44,8-68,0 mm SL), rio dos Sinos at João Fernandes beach near Caraá, 2946'27"S 50²6’08"W, 14 Dec 1995. MCP 19439 (5 of 13, 28,0-89,7 mm SL), arroio Carvalho at Caraá, 2948'04"S 50²8'25"W, 14 Jan 1996.

\section{Discussion}

Due to similarity of overall body shape, A. henseli may be mistakenly identified as A. fasciatus Cuvier (1819) according to the definition of this species proposed by Eigenmann (1921). The original description of $A$. fasciatus was based on a specimen (MNHN A.8653) collected in the rio São Francisco drainage, which was sent to MNHN by Delalande (Eigenman, 1921). Astyanax fasciatus has been reported from many river drainages from northern Mexico to northern Argentina. Recently, Melo (2005) concluded that the name A. fasciatus should only be applied to specimens from the rio São Francisco drainage; specimens usually identified as $A$. fasciatus from rio Paraná, eastern Brazil and Central America represent a complex of similar species. Astyanax fasciatus is diagnosed by the presence of an elongated dorsal fin in mature males (Fig. 5). Astyanax henseli, however, may be easily distinguished from populations of $A$. fasciatus from the rio São Francisco drainage, and other species from the $A$. fasciatus species complex, based on dentary tooth shape (teeth are wider in A. fasciatus), number of maxillary teeth (only one in A. fasciatus), shape of maxilla (straight maxilla $v s$. anteriorly curved in A. fasciatus), position of cusps on tooth crown (cusps widely spaced in $A$. fasciatus), and presence of a second humeral spot.

Astyanax henseli is synpatric with another species of the A. fasciatus complex which we refer to as "Astyanax sp. aff. fasciatus" (Fig. 6, see Comparative Material below). Astyanax sp. aff. fasciatus is widespread in the laguna dos Patos system and the Uruguay drainage. Specimens of Astyanax sp. aff. fasciatus are very similar to specimens of the São Fran- 


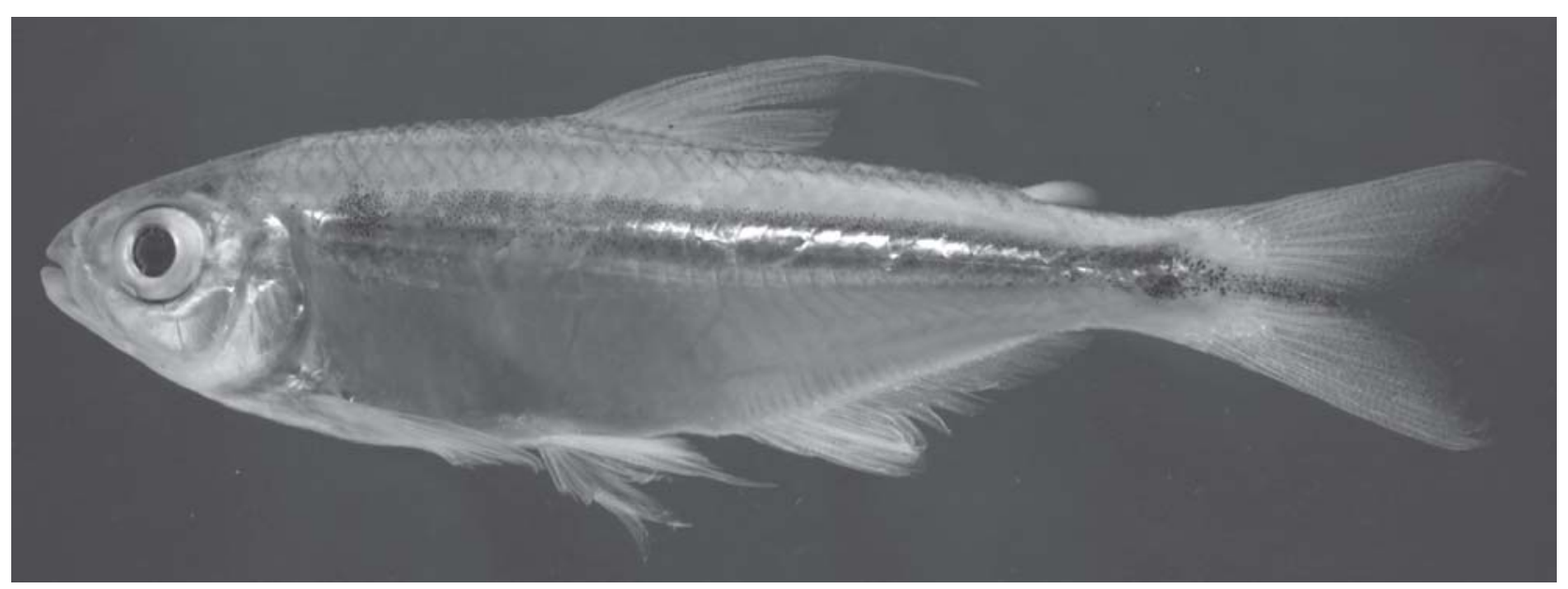

Fig. 5. Astyanax fasciatus, MZUSP 39263, 58.6 mm CP, male, Ilha Grande, rio São Francisco, Minas Gerais, Brazil.

cisco population of $A$. fasciatus. They differ from the São Francisco populations by usually having 5 [3(1), 4(9), 5(39), $6(1)]$ teeth in the outer row of the premaxilla, while the latter usually has $4[3(1), 4(38), 5(4), 6(1)]$ teeth in the outer row of the premaxilla. Establishing the status of Astyanax sp. aff. fasciatus is beyond the scope of the present publication. However, A. henseli differs from Astyanax sp. aff.fasciatus in the same way it differs from populations of $A$. fasciatus from the São Francisco drainage, including dentition characters. Astyanax sp. aff. fasciatus and most Astyanax species have the cusps of the dentary teeth more evenly distributed over the relatively wider crown (Fig. 7).

Steindachner (1876:17) included $A$. henseli (listed as Tetragonopterus aeneus Hensel) as a synonym of T. rutilus Jenyns, originally described from the rio Paraná. The latter is currently considered a synonym of $A$. fasciatus (e.g., Eigenman, 1921; Lima et al., 2003). However, our examination of the holotype of T. rutilus (BMNH 1917.7.14.14, Table 2) suggests that it may be a valid species (it has 37 total vertebrae vs. 35-
36 total vertebrae in $A$. fasciatus, mean=35.7, $\mathrm{n}=11$ ). Astyanax rutilus differs from $A$. henseli by the presence of only one maxillary tooth.

Astyanax henseli was listed by Buckup in Lima et al. (2003:111) as a junior synonym of $A$. obscurus. That listing was based on Steindachner's (1876:20) opinion that T. aeneus Hensel and T. obscurus were conspecific. However, Astyanax hensel $i$ is easily distinguished from $A$. obscurus based on the number of branched anal-fin rays (18-19 vs. 22-27 in $A$. henseli, Table 2), and the arrangement of dentary teeth. In $A$. obscurus the arrangement of the teeth is very similar to $A$. taeniatus Jenyns, $A$. giton Eigenmann, and $A$. intermedius Eigenmann. In those species the dentary teeth decrease gradually in size from anterior to posterior portion, unlike most species of Astyanax, which exhibit an abrupt reduction in size between the anterior and the posterior dentary teeth.

In addition to $A$. henseli and $A$. obscurus, five additional species of Astyanax from southern Brazil have been previously described: Astyanax jacuhiensis (Cope, 1894), A.

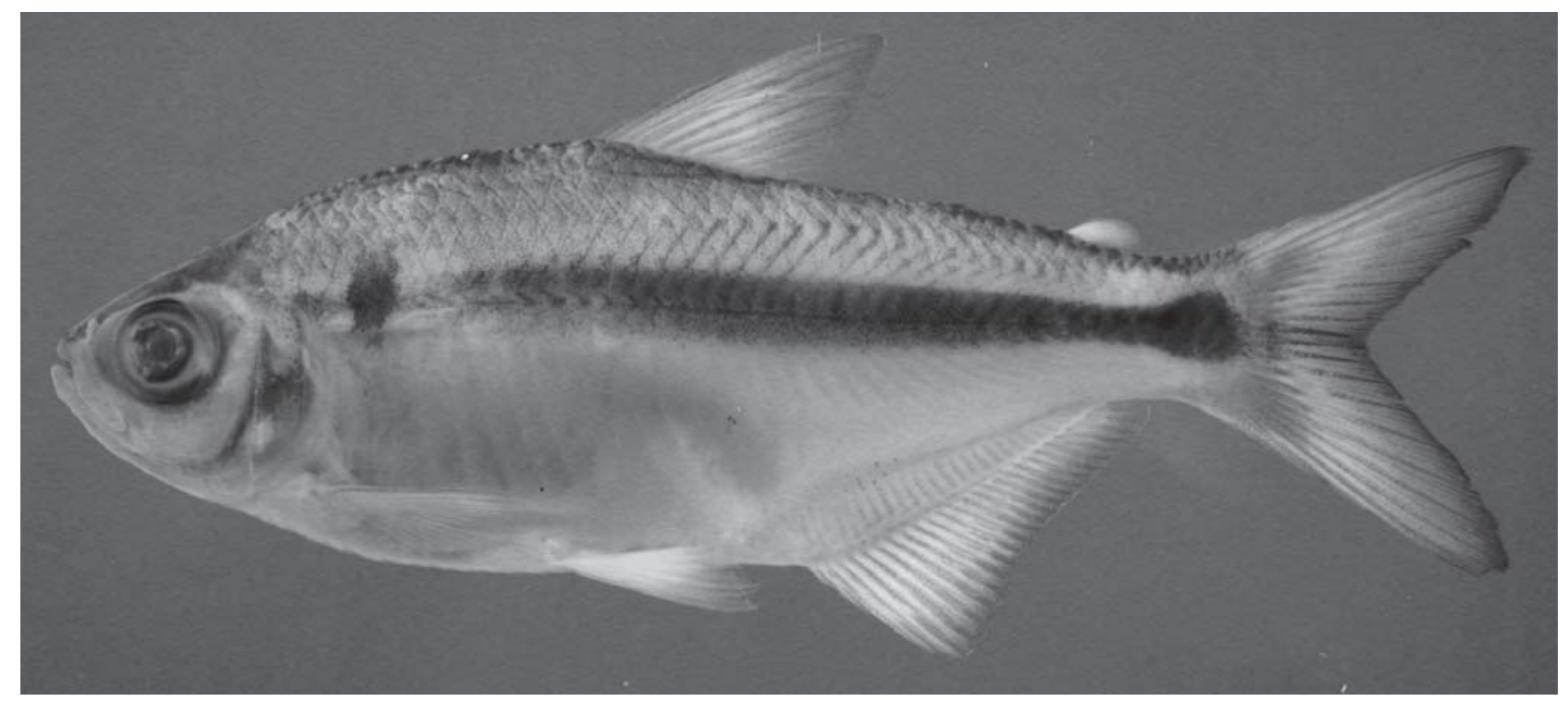

Fig. 6. Astyanax sp. aff. fasciatus, MNRJ 25570, 87.8 mm SL, male, lago Guaíba, Rio Grande do Sul, Brazil. 


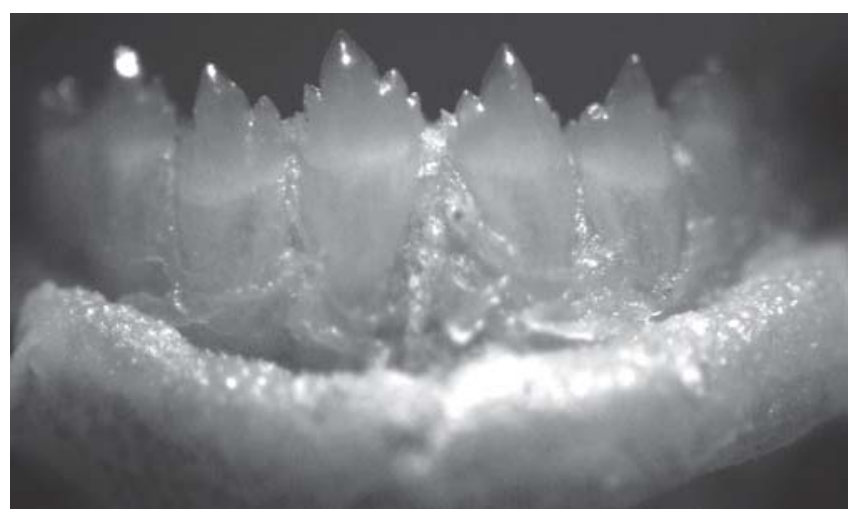

Fig. 7. Frontal view of dentary teeth of Astyanax sp. aff. fasciatus, MNRJ 25570, 65.8 mm SL, lago Guaíba, Rio Grande do Sul, Brazil.

eigenmanniorum (Cope, 1894), A. laticeps (Cope, 1894), A. brachypterygium Bertaco \& Malabarba, 2001, and $A$. cremnobates Bertaco \& Malabarba, 2001. Astyanax jacuhiensis belongs to Astyanax bimaculatus species-group and is distinguished from $A$. henseli by the absence of maxillar teeth, and by the shape of the humeral spot, which is horizontally oval. Astyanax laticeps, A. cremnobates and $A$. brachypterygium differ from $A$. henseli by their low number of branched anal-fin rays: 18-21, 14-18, and 12-16, respectively (Bertaco \& Malabarba, 2001). Astyanax henseli is distinguished from $A$. eigenmanniorum by the presence of two or more maxillary teeth, in addition to the autapomorphic spacing and shape of the dentary teeth.

It is unclear to us why Hensel (1870) described A. henseli as a new species, but used the name Tetragonopterus aeneus, which was pre-occupied by a Mexican species described a decade earlier by Günther (1860). Hensel (1970) apparently knew about Günther's publication, as evidenced by his own citation of Günther (1860). Regardless of his motives for publishing a homonymy, it is necessary to provide an available name for the species from Porto Alegre. Tetragonopterus aeneus (Günther) is a valid species from Central America currently included in the genus Astyanax (Schmitter-Soto, 1998). In spite of their sharing the same name and generic allocation, the two taxa are not conspecific. Astyanax aeneus (Günther) does not have the diagnostic characters of $A$.

Table 2. Morphometric and meristic data of the syntypes of A. aeneus (Günther, 1860), BMNH 1860.6.17.41-2, BMNH 1907.4.10.3, and A. obscurus (Hensel, 1870), ZMB 7478, and the holotype of Astyanax rutilus (Jenyns, 1842), BMNH 1917.7.14.14.

\begin{tabular}{|c|c|c|c|c|c|c|c|}
\hline & \multicolumn{3}{|c|}{ A. aeneus Günther } & \multirow[t]{2}{*}{ A. rutilus } & \multicolumn{3}{|c|}{ A. obscurus } \\
\hline & Range & Mean & $\mathrm{N}$ & & Range & Mean & $\mathrm{N}$ \\
\hline Standard length $(\mathrm{mm})$ & $65.8-80.0$ & 70.6 & 3 & 83.0 & $45.2-57.7$ & 52.6 & 3 \\
\hline Head length $(\mathrm{mm})$ & $17.3-20.4$ & 18.5 & 3 & 19.5 & $13.6-16.4$ & 15.4 & 3 \\
\hline \multicolumn{8}{|c|}{ Percents of standard length } \\
\hline Body depth & $38.7-43.7$ & 40.6 & 3 & 40.0 & $32.7-37.2$ & 34.8 & 3 \\
\hline Head length & $25.4-27.1$ & 26.3 & 3 & 23.4 & $28.5-30.0$ & 29.4 & 3 \\
\hline Caudal peduncle depth & $11.7-13.5$ & 12.7 & 3 & 11.0 & $11.9-12.5$ & 12.3 & 3 \\
\hline Snout to dorsal-fin origin & $51.6-52.4$ & 52.0 & 3 & 52.2 & $53.8-57.8$ & 55.2 & 3 \\
\hline Snout to anal-fin origin & $64.1-66.5$ & 65.2 & 3 & 66.4 & $65.7-68.6$ & 67.3 & 3 \\
\hline Snout to pelvic-fin origin & $47.0-50.7$ & 48.8 & 3 & 48.7 & $49.3-55.3$ & 52.4 & 3 \\
\hline Snout to pectoral-fin origin & $26.7-28.3$ & 27.5 & 3 & 26.4 & $26.8-30.1$ & 28.7 & 3 \\
\hline Dorsal-fin origin to caudal-fin origin & $55.5-56.0$ & 55.7 & 3 & 53.3 & $51.5-52.6$ & 52.4 & 3 \\
\hline Anal-fin base & $27.8-29.9$ & 29.0 & 3 & 29.8 & $21.6-23.4$ & 22.3 & 3 \\
\hline Length of longest anal-fin ray & $14.0-19.5$ & 16.8 & 3 & 17.7 & $20.0-24.9$ & 21.7 & 3 \\
\hline Length of longest dorsal-fin ray & $26.8-29.3$ & 28.1 & 3 & 25.9 & $24.8-25.9$ & 25.3 & 3 \\
\hline Dorsal-fin origin to adipose-fin origin & $39.9-40.6$ & 40.3 & 3 & 37.3 & $35.3-36.1$ & 35.7 & 3 \\
\hline Dorsal-fin base & $13.9-14.5$ & 14.1 & 3 & 12.4 & $12.7-13.5$ & 13.1 & 3 \\
\hline Pectoral-fin length & $21.4-23.6$ & 22.4 & 3 & 22.3 & $21.1-22.7$ & 22.2 & 3 \\
\hline Pelvic-fin length & $16.8-17.7$ & 17.3 & 3 & 17.4 & $14.4-15.7$ & 15.2 & 3 \\
\hline Caudal peduncle length & $10.9-12.9$ & 11.6 & 3 & 12.5 & $14.1-14.9$ & 14.5 & 3 \\
\hline Eye to dorsal-fin origin & $39.8-41.8$ & 41.0 & 3 & 40.3 & $39.2-42.2$ & 40.4 & 3 \\
\hline \multicolumn{8}{|c|}{ Percents of head length } \\
\hline Snout length & $19.7-22.0$ & 21.1 & 3 & 23.0 & $21.2-23.4$ & 22.1 & 3 \\
\hline Orbital diameter & $38.7-40.4$ & 39.6 & 3 & 43.9 & $39.5-44.5$ & 42.1 & 3 \\
\hline Interorbital width & $33.5-36.1$ & 35.2 & 3 & 35.7 & $27.7-28.6$ & 28.2 & 3 \\
\hline Upper jaw length & $42.0-44.5$ & 43.2 & 3 & 42.9 & - & - & - \\
\hline \multicolumn{8}{|c|}{ Counts } \\
\hline Teeth in outer row of premaxilla & 4 & 4 & 3 & 5 & $4-5$ & 4.7 & 3 \\
\hline Teeth in inner row of premaxilla & $4-5$ & 4.3 & 3 & 4 & $3-5$ & 4.0 & 3 \\
\hline Teeth in maxilla & $1-2$ & 1.3 & 3 & 1 & 1 & 1 & 3 \\
\hline Unbranched anal-fin rays & 3 & 3 & 3 & 3 & 3 & 3 & 3 \\
\hline Branched anal-fin rays & $23-27$ & 24.7 & 3 & 26 & $18-19$ & 18.7 & 3 \\
\hline Dorsal-fin rays & $\mathrm{ii}+9$ & $\mathrm{ii}+9$ & 3 & $\mathrm{ii}+9$ & $\mathrm{ii}+9$ & $\mathrm{ii}+9$ & 3 \\
\hline Pelvic-fin rays & $i+7$ & $\mathrm{i}+7$ & 3 & $i+7$ & $i+7$ & $\mathrm{i}+7$ & 3 \\
\hline Lateral line scales & $36-39$ & 37.3 & 3 & 39 & $35-38$ & 36.7 & 3 \\
\hline Scales rows between lateral line and dorsal fin & 7 & 7 & 3 & 8 & $6-7$ & 6.3 & 3 \\
\hline Scales rows between lateral line and anal fin & $6-7$ & 6.7 & 3 & 8 & $5-6$ & 5.3 & 3 \\
\hline Predorsal scales & $11-15$ & 12.3 & 3 & 13 & $12-13$ & 12.3 & 3 \\
\hline Scales around caudal peduncle & $15-16$ & 15.7 & 3 & 16 & 15 & 15 & 3 \\
\hline
\end{tabular}


henseli. In addition, $A$. henseli is easily distinguished from $A$. aeneus (Günther) by its larger orbital diameter (42.4-50.7\% of HL vs. 38.7-40.4\% of HL in A. aeneus, Tables 1-2).

Comparative material. Astyanax fasciatus: MNHN A.8653, holotype, $120.8 \mathrm{~mm} \mathrm{SL}$; MNRJ 17366, 17, 10 measured, 49.2-72.3 mm SL, 1 c\&s; MNRJ 21489, 47, 4 measured, 60.9-71.1 mm SL; MNRJ 21828, 419, 52.1-67.0 mm SL, 3 c\&s; MNRJ 22274, 239, 10 measured, 44.2-82.3 mm SL; MNRJ 22817, 40, 5 measured, 46.4-65.5 mm SL; MNRJ 24054, 177, 36.3-69.2 mm SL, 8 c\&s; MZUSP 39263, 11, 34,2-58,1 mm SL. Astyanax sp. aff. fasciatus: MNRJ 14201, 2, 100.9-106.2 mm SL; MNRJ 25607, 33, $15.6-$ 61.4 mm SL; MNRJ 25570, 7, 54.4-105.6 mm SL; MNRJ 25581, 93, 13.9-66.6 mm SL; MNRJ 28871, 1, 25.4 mm SL; MCP 9436, 25 of 62, 35.0-48.8 mm SL; MCP 21378, 25 of 48, 46.6-59.7 mm SL; MCP 25841, 2, 56.8-61.0 mm SL; MCP 25958, 5 of 12, 56.182,6 mm SL; MCP 28278, 5 of 17, 46.1-65.5 mm SL; MCP 34927 , 5 of 26, 63.7-72.0 mm SL. Astyanax eigenmanniorum: ANSP 21598, holotype, $48.1 \mathrm{~mm} \mathrm{SL}$; ANSP 21599-21601, paratypes, 36.7-51.9 mm SL. Astyanax intermedius: CAS 42485, lectotype, 45.8 mm SL. Astyanax giton: MCZ 20936, lectotype, $63.3 \mathrm{~mm}$ SL; MNRJ 20832, 63, 40.2-93.5 mm SL. Astyanax taeniatus: UMZC V.329, 2 syntypes, 40.5-41.3 mm SL. Tetragonopterus aeneus Günther: BMNH 1860.6.17.41-2, 2 syntypes, 65.8-66.0 mm SL; BMNH 1907.4.10.03, 1 syntype, 80.0 mm SL. Tetragonopterus obscurus: ZMB 7478, 3 syntypes, 45.2-57.5 mm SL. Tetragonopterus rutilus: BMNH 1917.7.14.14, holotype, $83.0 \mathrm{~mm}$ SL.

\section{Acknowledgements}

Darrel Siebert provided access to BMNH research facilities. The type material of T. rutilus and A. aeneus were Xrayed by Juan P. Garcia and D. Siebert. We thank Luiz R. Malabarba (MCP) and Peter Bartch (ZMB) for the loan of the type material of $A$. henseli and $A$. obscurus. We are greateful to Luiz R. Malabarba and Vinicius A. Bertaco (MCP) for selection and loan of MCP specimens. This research was supported by graduate fellowships from Coordenação de Aperfeiçoamento de Pessoal de Nível Superior - CAPES (Process BEX0644/02-1, and Programa Demanda Social-PPGZOO/ UFRJ), and research grants from CNPq (PRONEX Project "Conhecimento, conservação e utilização racional da biodiversidade de peixes do Brasil", FINEP/CNPq, N $^{\circ} 664058 /$ 1997-2; Project "Sistemática e Biogeografia de Peixes de Riachos", Proc. CNPq 473652/2003-0, Proc. CNPq 308387/20031 , and associated fellowships). This paper is part of a doctoral dissertation by Filipe A. G. de Melo, in the Programa de Pós-Graduação em Ciências Biológicas (Zoologia) of the Museu Nacional, Universidade Federal do Rio de Janeiro. We also thank Marcelo R. Britto, Vinicius A. Bertaco, and an anonymous reviewer for critically reading the manuscript.

\section{Literature cited}

Azpelicueta, M. M., A. E. Almiron \& E. J. R. Casciottta. 2002. Astyanax paris: A new species from the Rio Uruguay basin of Argentina (Characiformes, Characidae). Copeia, (4): 1052-1056. Azpelicueta, M. M., J. M. Mirande, A. E. Almiron \& E. J. R. Casciotta. 2003. A new species of Astyanax (Characiformes,
Characidae) from Paraná river basin in Argentina. Revista del Museo de La Plata, Zoología, 15(166): 1-12.

Baird, F. S. \& C. Girard, 1854. Descriptions of new species of fishes collected in Texas, New Mexico and Sonora, by Mr. John H. Clark, on the U.S. and Mexican Boundary Survey, and in Texas by Capt. Stewart Van Vliet, U.S.A. Proceedings of the Academy Natural Sciences, Philadelphia, 1854: 24-29.

Bertaco, V. A. \& P. H. F. Lucinda. 2005. Astyanax elachylepis, a new characid fish from the rio Tocantins drainage Brazil (Teleostei: Characidae). Neotropical Ichthyology, 3(3): 389-394.

Bertaco, V. A. \& L. R. Malabarba. 2001. Description of two new species of Astyanax (Teleostei: Characidae) from headwater streams of Southern Brazil, with comments on the " $A$. scabripinnis species complex". Ichthyological Exploration of Freshwaters, 12(3): 221-234.

Casciotta, J. R., A. E. Almiron \& M. M. Azpelicueta. 2003. A new species of Astyanax from rio Uruguay basin, Argentina (Characiformes: Characidae). Ichthyological Exploration of Freshwaters, 14(4): 329-334.

Cope, E. D. 1894. On the fishes obtained by the naturalist expedition in Rio Grande do Sul. Proceedings of the American Philosophical Society, 33: 84-108.

Cuvier, G. 1819. Sur les poissons du sous-genre Hydrocyon, sur deux nouvelles especes de Chalceus, sur trois nouvelles especes de Serrasalmes, et sur l'Argentina glossodonta de Forskahl, qui est 1'Albula gonorhynchus de Bloch. Mémoirs du Museum D'Historie Naturelle. Paris, 5: 351-379.

Eigenmann, C. H. 1910. Catalogue of fresh water fishes of tropical and South America. Reports of the Princeton University Expedition to Patagonia, 1896-1899, 3(4): 375-511.

Eigenmann, C. H. 1921. The American Characidae. Memoirs of the Museum of Comparative Zoology, 23(3): 209-310.

Fink, W. L. \& S. H. Weitzman. 1974. The so-called cheirodontin characids of Central America, with descriptions of two new species (Pisces: Characidae). Smithsoninan Contributions to Zoology, 172: 1-46.

Fowler, H. W. 1948. Os peixes de água doce do Brasil ( $1^{\text {a }}$ entrega). Arquivo de Zoologia do Estado de São Paulo, 6: 1-204.

Garutti, V. \& H. A. Britski. 2000. Descrição de uma espécie nova de Astyanax (Teleostei: Characidae) da bacia do Alto Rio Paraná e considerações sobre as demais espécies do gênero na bacia. Comunicações do Museu de Ciências e Tecnologia da PUCRS, Série Zoologia, 13: 65-88.

Günther, A. 1864. Catalogue of the Physostomi, containing the families Siluridae, Characinidae, Haplochitonidae, Sternoptychidae, Sopelidae, Stomiatidae, in the collection of the British Museum, London. 325p.

Haluch, C. F. \& V. Abilhoa. 2005. Astyanax totae, a new characid species (Teleostei: Characidae) from the upper rio Iguaçu basin, southeastern Brazil. Neotropical Ichthyology, 3(3): 383-388.

Hensel, R. 1870. Beiträge zur Kenntniss der Wirbelthiere Südbrasiliens. Archiv für Naturgeschichte, 36(1): 86-87.

Lima, F. C. T., L. R. Malabarba, P. A. Buckup, J. F. Pezzi da Silva, R. P. Vari, A. Harold, R. Benine, O. T. Oyakawa, C. S. Pavanelli, N. A. Menezes, C. A. S. Lucena, M. C. S. L. Malabarba, Z. M. S. Lucena, R. E. Reis, F. Langeani, L. Casatti, V. A. Bertaco, C. Moreira \& P. H. F. Lucinda. 2003. Genera Incertae Sedis in Characidae. Pp. 106-169. In: Reis, R. E., S. O. Kullander \& C. J. Ferraris Jr. (Eds.). Check list of the freshwater fishes of South and Central America. Porto Alegre, Edipucrs. 729p.

Lima, F. C. T. \& J. Zuanon. 2004. A new species of Astyanax (Characiformes: Characidae) from the rapids of the lower rio 
Xingu, Brazil. Neotropical Ichthyology, 2(3): 117-122.

Malabarba, L. R. 1989. Histórico sistemático e lista comentada das espécies de peixes de água doce do sistema da Laguna dos Patos, Rio Grande do Sul, Brasil. Comunicações do Museu de Ciências e Tecnologia da PUCRS, Série Zoologia, 2(8): 107-179.

Melo, F. A. G. 2001. Revisão taxonômica das espécies do gênero Astyanax Baird \& Girard, 1854 (Teleostei: Characiformes: Characidae) da região da Serra dos Órgãos. Arquivos do Museu Nacional, 59: 1-46.

Melo, F. A. G. 2005. Revisão taxonômica do complexo de espécies Astyanax fasciatus (Cuvier, 1819) (Teleostei: Characiformes: Characidae). Unpublished Ph.D. Dissertation. Museu Nacional, UFRJ.

Schmitter-Soto, J. J. 1998. Diagnosis of Astyanax altior (Characidae), with a morphometric analysis of Astyanax in the Yucatan Peninsula. Ichthyological Exploration of Freshwaters, 8(4): 349-358.

Steindachner, F. 1876. Die Süsswasserfische des südöstlichen Brasilien (III). Sitzungeberichte der Akademie der Wissenschafften, 74: 559-694.
Taylor, W. R. \& G. C. Van Dyke. 1985. Revised procedures for staining and clearing small fishes and other vertebrates for bone and cartilage. Cybium, 9: 107-119.

Weitzman, S. H. \& W. Fink. 1983. Relationships of the Neon Tetras, a group of South American freshwater fishes (Teleostei, Characidae) with comments on the phylogeny of new world Characiforms. Bulletin of the Museum of Comparative Zoology, 150(6): 339-395.

Weitzman, S. H. \& L. R. Malabarba. 1998. Perspectives about the phylogeny and classification of the Characidae (Teleostei: Characiformes). Pp. 161-170. In: L. R. Malabarba, R. E. Reis, R. P. Vari, Z. M. S. Lucena \& C. A. S. Lucena (eds.). Phylogeny and Classification of Neotropical Fishes. Edipucrs, Porto Alegre. $603 \mathrm{p}$.

Zanata, A. M. 1997. Jupiaba, um novo gênero de Tetragonopterinae com osso pélvico em forma de espinho (Characidae, Characiformes). Iheringia, Série Zoologia, 83: 99-136.

Received June 2005 Accepted December 2005 